\title{
TEORIA CENTRUM-PERYFERII IMMANUELA WALLERSTEINA I JEJ RECEPCJA W ARCHEOLOGII. STUDIUM PRZYPADKU: EGEJSKI SYSTEM-ŚWIAT W EPOCE BRĄZU
}

\section{IMMANUEL WALLERSTEIN'S CENTRE-PERIPHERY THEORY AND ITS RECEPTION IN ARCHEOLOGY. THE CASE STUDY OF AEGEAN BRONZE AGE WORLD-SYSTEM}

\author{
Adriana Ciesielska \\ Zakład Zasobów Poznawczych Człowieka \\ Wydział Pedagogiczno-Artystyczny \\ Uniwersytet im. Adama Mickiewicza, Poznań - Kalisz, Poland \\ adrianac@wp.pl
}

\begin{abstract}
This paper present the work of Nick Kardulias concerning the Egean World - System In the Bronze Age. It is paradoxical that the application of the Wallerstein's model is the most popular and the most useful in Bronze Age studies. In the current article I assess the Kardulias' work, his worldsystems approach to Aegean societies in the third and second millennia BC. He writes that in this era of the studied area societies developed complex economies based on accumulation of substantial agricultural surpluses, craft specialization, and intricate distribution systems.
\end{abstract}

KEY WORDS: world-systems theory, bronze age, economy, social relationships, economic model

Artykuł ma na celu przedstawienie polskiej społeczności archeologicznej dorobku Nicka Karduliasa, amerykańskiego archeologa i antropologa, który był głównym propagatorem koncepcji systemów-światów Immanuela Wallersteina w archeologii światowej. Nick Kardulias razem z Thomasem D. Hallem i Christoperem Chase- 
Dunnem napisali dwa artykuły $(2008,2011)$ oceniające aplikację modelu centrum-peryferii Immanuela Wallersteina w archeologii. Paradoksem jest to, że najlepiej i najpowszechniej recepcja tej teorii odbywa się podczas studiów nad epoką brązu, być może dlatego, ponieważ badacze przypuszczają, że jest to okres, kiedy kształtowały się po raz pierwszy złożone społeczności.

Nick Kardulias w swoim najsłynniejszym artykule z 1999 roku czyni kilka nowych spostrzeżeń dotyczących epoki brązu w basenie Morza Egejskiego. Pierwszą z nich jest założenie, że egejskie społeczności w III i w II tysiącleciu p.n.e. rozwinęły złożone gospodarki oparte na akumulacji istotnych rolniczych nadwyżek, specjalizacji rzemieślniczej i rozległych, złożonych systemów dystrybucji. Nick Kardulias wyróżnia trzy główne poziomy tego złożonego systemu handlu. Przedmioty, którymi handlowano, obejmowały zarówno masowe wyroby, jak i przedmioty luksusowe. Co więcej, stara się on uzasadnić pogląd, że egejska ekonomia w epoce brązu była dodatkiem do wschodniośródziemnomorskiego systemu-świata, a w sposób znikomy łączyła się z gospodarką Europy Środkowej i Zachodniej. Jego zdaniem świadectwa archeologiczne sugerują istnienie systemu z lokalnymi, międzyregionalnymi i ponadregionalnymi komponentami.

Studia Nicka Karduliasa są bardzo użyteczne, ponieważ Immanuel Wallerstein nie zajmował się $\mathrm{w}$ swoich studiach społecznościami będącymi na przedkapitalistycznym poziomie wymiany.

\section{PRZELAMANIE MODELU CENTRUM-PERYFERII IMMANUELA WALLERSTEINA}

Nick Kardulias, akceptując model Immanuela Wallersteina, jest równocześnie świadomy jego ograniczeń. Immanuel Wallerstein w swoich pracach (do tej pory wydał cztery) na ten temat opisuje system-świat jako jeden z tylko dwóch prawdziwych systemów społecznych. Według niego drugim, nazwanym mini-systemem, jest mała, izolowana społeczność z autonomicznym sposobem produkcji, taka jak na przykład!Kung San na pustyni Kalahari w południowej Afryce. Takie mini-systemy są samowystarczalne i ich dynamika rozwojowa jest w dużym stopniu wewnętrzna. Systemy-światy są zdefiniowane przez to, że ich samowystarczalność, jako całości ekonomiczno-materialnej, oparta jest na rozległym, osiowym podziale pracy i że zawierają one w swoim obrębie wiele kultur. Immanuel Wallerstein (1974) rozróżnił dwa typy systemów-światów: imperia-światy i gospodarki-światy. Różnica między nimi opiera się na obecności w tym pierwszym pojedynczej struktury politycznej dominującej nad olbrzymim obszarem. Według Immanuela Wallersteina kapitalizm dostarczył stabilności nowożytnej gospodarki-świata, która wyłoniła się w XV wieku. Gospodarka ta stworzyła arenę dla wzajemnych stosunków wśród dużej liczby państw narodowych, co z kolei pozwoliło na dostarczenie środków do ustawicznej 
ekspansji europejskiego systemu-świata w okresie między XVI a XVII wiekiem. Co więcej, działanie gospodarki-świata wymaga obecności państw centralnych i stref peryferyjnych. Państwa centralne przedstawiają złożone polityczne struktury, stratyfikowany system klasowy z wielką biurokracją i za pomocą nadrzędnej technologii kontrolują udogodnienia produkcji, transportu i komunikacji. Organizacja polityczna na obszarach peryferyjnych, w porównaniu z tą na obszarze centralnym, na etapie przedpaństwowym lub w początkowym stadium państwowym jest względnie słaba. Państwa centralne włączają strefy peryferyjne w kapitalistyczną gospodarkę-świat, ponieważ te peryferyjne regiony często zawierają ważne naturalne zasoby. Europejskie państwa centralne kontrolowały podział pracy i zachowały te zadania, które wymagały wyższego poziomu zdolności i inwestycji kapitału dla obszarów wyżej stojących w hierarchii, czyli samej Europy. Poprzez polityczną, ekonomiczną kontrolę systemu Immanuel Wallerstein rozumie, że państwa centralne eksploatowały pracę i materialne surowce obszarów peryferyjnych i otrzymywały nieproporcjonalnie wielki udział w nadwyżce czy korzyściach. Europejskie państwa narodowe konkurowały między sobą o kontrolę i dostęp do obszarów peryferyjnych, aby zwiększyć swoje zyski.

Wyobrażenie Immanuela Wallersteina o rodzącej się gospodarce-świecie i relacji między centrum a peryferiami dostarcza doskonałego modelu europejskiej ekspansji we wczesnej erze nowożytnej. Zaprezentowanie przez I. Wallersteina włączania do gospodarki-świata peryferii, jako w dużej mierze nieukierunkowanego zjawiska, zdaniem Nicka Karduliasa (1999) jest uproszczeniem złożonego procesu. N. Kardulias odwołuje się w tym miejscu do prac Thomasa D. Halla oraz Christophera Chase-Dunna. T. Hall oraz Ch. Chase-Dunn (1991) twierdzą, że należy badać lokalne warunki w obszarach peryferyjnych, jak również gospodarkę kapitalistyczną na obszarach centralnych, aby zrozumieć w pełni naturę włączania jako zjawisko zmienne.

Thomas D. Hall i Christopher Chase-Dunn (1991) zakładają, że inkorporacja do gospodarki-świata jest kwestią stopnia rozwoju i niepaństwowe, peryferyjne społeczności odgrywają w niej bardziej aktywną rolę, niż przypuszczano na początku. Jest to szczególnie widoczne dla różnych okresów w starożytności, kiedy całkowita dominacja stref peryferyjnych była niemożliwa politycznie i technologicznie.

Wielkim problemem jest określenie stopnia, w jakim model systemów-światów można zastosować do starożytnego świata. Immanuel Wallerstein sugeruje, że system-świat wyrósł z kapitalizmu, tak więc jest tworem XVI wieku. Z kolei Fernand Braudel (1977) wierzy, że taki system-świat istniał w starożytności. Ważnym momentem, zdaniem Nicka Karduliasa (1999), były dokonania Philipa Kohla, który zrewidował system-świat, aby odpowiadał warunkom starożytności. W ostrożnej krytyce prymitywistów i pracy Mosesa I. Finleya i innych Philip Kohl cytuje wiele przykładów ustalania cen, inflacji i rynkowej mentalności, która demonstruje złożoność starożytnej ekonomii. Podaje on poważne argumenty za istnieniem wzajemnie 
się łączącego systemu-świata o wielu centrach podczas epoki brązu w południowo-zachodniej Azji. W kontraście do nowożytnych gospodarek-światów, starożytne technologie były łatwe do przeniesienia z centrum do peryferii, a te ostatnie mogły zaoferować swoje zasoby konkurującym państwom i w ten sposób zachować swoją autonomię. Brak wielkiej kolonizacji uniemożliwiał eksploatację i brak rozwoju peryferii. Philip Kohl analizuje relacje centrum-peryferia w kontekście obszaru transkaukaskiego i dostarcza pojęć użytecznych dla badania egejskiej epoki brązu. Nick Kardulias (1999), za Philipem Kohlem, zapożycza pojęcie prowincji metalurgicznych od Eugeniusza Chernykha, zdefiniowanych jako dzielone użytkowanie typologicznie podobnych ozdób metalowych, narzędzi i broni przez wspólną technologię metalurgicznej produkcji i przez dostęp do tych samych metalurgicznych surowców. To, co Eugeniusz Chernykh i Philip Kohl zamierzali wypracować dla badań nad obszarem transkaukaskim, zdaniem Nicka Karduliasa (1999) jest równie stosowalne dla obszaru egejskiego. Jeżeli cyna nie była otrzymywana lokalnie na obszarze transkaukaskim od późnej epoki brązu w górę, i podobnie było na obszarze basenu Morza Egejskiego, na podstawie znalezisk tzw. cynowego brązu, czyli brązu z zawartością cyny na tych terenach, wnosi się, że istniały połączenia między regionami z prawdziwymi zależnościami ekonomicznymi, z obszarami, które ten surowiec posiadały. Obszary posiadające ten surowiec nie mogą być jednak traktowane wyłącznie jako czyste peryferia. Obszary egejskie i transkaukaskie słabo odzwierciedlają cywilizację emanującą z Bliskiego Wschodu. Raczej to Egea i Transkaukazja stymulowały Bliski Wschód i głęboko wpływały na bieg ich rozwoju.

Analogiczne założenia jak Philip Kohl, zdaniem Nicka Karduliasa (1999), wysuwa Alen Zagarell, który ponownie definiuje relacje między pasterskimi społeczeństwami a wczesnymi państwami. Podobne osadnictwo i wzory wyżywienia charakteryzowały zarówno niziny, jak i wyżyny Mezopotamii, aż do późnego środkowego chalkolitu. Wówczas na wyżynach pojawiły się małe osady i pasterstwo przemieszczające się z miejsca na miejsce, podczas gdy osady na aluwialnych równinach urosły w swojej wielkości i zintensyfikowały rolnictwo irygacyjne. Zdaniem Alena Zagarella podejmowane przez społeczeństwa na obu obszarach działania prowadziły do rozwoju produkcji, aby zintensyfikować zyski. Z powodu ograniczeń środowiskowych wyżyny i ich społeczeństwa nie potrafiły naśladować modelu nizinnego, czyli ekspansji rolnictwa. Aby zwiększyć produkcję, mieszkańcy wyżyn, porzucając rolnictwo, zajęli się pasterstwem nomadycznym na wielką skalę. W doskonałej dyskusji tego uzupełniającego się rozwoju A. Zagarell zauważa, że nie ma wewnętrznego antagonizmu między społeczeństwami pasterskimi a państwowymi. Ta ocena ma oczywiście jasne implikacje dla wymiany ekonomicznej między takimi populacjami i przedstawia model interakcji centrum-peryferie, który nie ma nowożytnych analogii.

W recenzji aplikacji systemów światów Edward M. Schortman i P. A. Urban (1987, 1992) wskazują na niektóre problemy związane z użyciem podejścia systemów-światów w archeologii. Po pierwsze uznają oni za ograniczającą definicję 
społecznego systemu Immanuela Wallersteina szczególnie w kategoriach ekonomicznych. Po drugie problematyczne jest dla nich porzucenie zmiennych kulturowych jako ważnych czynników składowych w procesach interakcji. Znaczącą trudnością ich zdaniem jest twierdzenie Immanuela Wallersteina, że przedkapitalistyczne systemy-światy nie istniały. Na jego twierdzenie, że przedkapitalistyczne imperia były wewnętrznie niestabilne, nie ma żadnych empirycznych dowodów. Kluczowy jest nacisk I. Wallersteina na ekonomiczne aspekty handlu, który zaciemnia nieekonomiczne i niematerialne aspekty zarówno handlu, jak i innych typów interakcji. M. Schortman i P. A. Urban sugerują w swoim modelu międzyspołecznego kontaktu jednostkę analizy, którą powinno być społeczeństwo i etniczność. Są powiązane z przepływem informacji, energii, materiałów społecznych, instytucji i idei. Zakładają, że tylko informacje mają zdolność wymuszania pozytywnych reakcji w relacjach między społeczeństwami, które miałyby rozwojowe znaczenie. Tak więc nie tylko handel, ale także czynniki, takie jak zmiana w ideologii, zainspirowana przez wprowadzenie obcych informacji, może wytworzyć zmianę społeczną. Ponieważ różni członkowie sieci wymiany są pod wpływem tej interakcji, M. Schortman i P. A. Urban używają pojęcia koewolucji, aby opisać sytuację wyraźnej interakcji międzyspołecznej. Podczas gdy Nick Kardulias zgadza się, że wąskie skupienie się na handlu upraszcza proces interakcji. Sądzi on, że skoncentrowanie się na problemie materialności wyjaśnia bardziej zmiany w archeologicznych źródłach. Czym są dokładnie zmiany w procesie koewolucji? Pierwszoplanowym efektem jest zmiana w produkcji: może być postrzegana w kategoriach intensyfikacji, szczególnej techniki czy też ekspansji terytorialnej celem zwiększenia obszaru dostępności surowców. Wybór typu prowadzącego do intensyfikacji produkcji zależeć będzie głównie od hierarchii wartości w danym społeczeństwie, co wpłynie na realizację nowych celów, w zależności od tego, czy nowe cele są materialne, czy też ideologiczne. W związku z tym cele materialne można osiągać przez zwiększenie nadwyżki produkcji, zaś niektóre cele ideologiczne takiej nadwyżki nie wymagają. Nie mając możliwości poznania myśli dawno nieżyjących społeczeństw, możemy obserwować jedynie efekt ich działań w krajobrazie, jak i pozostałości poziomu ich zdolności pracy wytwórczej w odkrywanych archeologicznie osadach.

Celem analizy Karduliasa w trwającej dyskusji jest zademonstrowanie roli handlu w ekspansji produkcyjnej bazy w epoce brązu na Morzu Egejskim. Pojęcia dostarczone mu przez kilku przytoczonych wcześniej autorów były dla N. Kardiuliasa użyteczne w jego pracach i opisanym celu.

Christopher Chase-Dunn i Thomas D. Hall (1991) sugerowali rewizję teorii systemów-światów, aby uczynić ją stosowną do szerszego historycznego i geograficznego kontekstu. W swojej pracy położyli główny nacisk na założenie, że fundamentalną jednostką historycznego rozwoju nie jest pojedyncze społeczeństwo, lecz cały międzyspołeczny kontekst, w obrębie którego pojedyncze społeczeństwo istnieje. Ich celem było dostarczenie porównawczego wzoru, w obrębie którego będzie moż- 
na studiować kontakty wszystkich społeczeństw, nawet bezpaństwowych grup łowców, zbieraczy. Według nich interakcje w rosnącym porządku kontekstu regionalnego obejmują: wymianę dóbr żywnościowych, wzajemną wymianę polityczną czy militarną, wymianę dóbr prestiżowych oraz przepływ informacji i dóbr kulturowych; skoncentrowane interakcje mogą być umieszczone w rozległych systemach.

Niezwykle istotna dla dalszych studiów jest definicja Ch. Chasa-Dunna i T. Halla dwóch rodzajów relacji centrum-peryferia. Pierwszy nazywają rozróżnieniem centrum i peryferii (centre-perifery defferenciation), w którym społeczności na różnych poziomach złożoności i gęstości populacji są w interakcji jeden $\mathrm{z}$ drugim $\mathrm{w}$ obrębie tego samego systemu-świata, jak zdefiniowany wyżej. W drugim typie mamy hierarchie centrum i peryferii (centre-perifery hierarchy), która będzie rozumiana jako istnienie politycznych, ekonomicznych i ideologicznych dominacji między różnymi społeczeństwami w obrębie tego samego systemu-świata. T. Hall i Ch. Chase-Dunn (1991) wyróżniają te dwa typy interakcji, ponieważ za błąd uważają to, że wszystkie relacje między lepiej rozwiniętymi i mniej rozwiniętymi społecznościami obejmują eksploatację i procesy rozwoju niedorozwoju (under development), których przykłady są w dziesiątkach znajdowane w nowożytnym systemie-świecie.

To rozróżnienie określa typ interakcji, który Philip Kohl opisuje dla południowo-zachodniej Azji w epoce brązu. To, o czym pisze Kohl, to rozróżnienie centrum-peryferie. Nick Kardulias wierzy, że to samo pojęcie stosuje się do systemu handlowego Egei w epoce brązu. Chase-Dunn i Hall proponują także trójdzielny podział systemów-światów oparty na złożoności społecznej najbardziej rozwiniętych społeczeństw w każdej kategorii:

1) dominujący tryb pokrewieństwa,

2) miejskie kultury i dominujący trybut,

3) dominujący tryb kapitalistyczny.

Kategoria druga obejmuje zarówno podstawowe imperia i systemy-światy o wielu centrach, w których strefy peryferyjne, imperia i autonomiczne państwa nawzajem wchodzą w interakcje.

System egejski wpasowuje się w tę drugą z trzech klas. Od tej teoretycznej klasyfikacji Ch. Chase-Dunn i T. Hall (1991) wysuwają cztery robocze hipotezy:

1) instytucje hierarchii społecznej są obowiązkowe do dominacji międzyspołecznych,

2) stratyfikacja w społecznościach centralnych wzmacnia zdolność hierarchii centrum-peryferia do eksploatacji stref peryferyjnych,

3) rozwój wymiany rynkowej, systemów monetarnych i innych mechanizmów handlu umożliwia rozprzestrzenianie się do peryferyjnych regionów społecznych i technologicznych elementów z centrum,

4) społeczne innowacje wydarzają się gotowe w półperyferyjnych strefach, ponieważ otrzymują wkład z centrum i peryferii i są nieograniczone przez rozległą kontrolę centrum. 
Ch. Chase-Dunn i T. Hall (1999) dostarczają dynamiczny, użyteczny model, przez który można zrozumieć zróżnicowania systemów-światów i przetestować podstawowe koncepcje.

Obecne studium Nicka Karduliasa (1999) jest po części odpowiedzią na ich prośby o studia przypadków, aby dostarczyć porównawcze dane niezbędne dla potwierdzenia ich hipotez.

Andrew Sherratt (1993) także używał pojęcia margines, aby odnosić się do strefy, która nie wchodzi bezpośrednio w interakcję z centrum, ale naprawdę dostarcza materiałów, które są krytyczne dla działania systemów-światów. Wskazuje tu na rolę bursztynu ze strefy bałtyckiej i różnych metali z centralnej Europy w systemie handlu basenu Morza Śródziemnego. Miejskie centra Bliskiego Wschodu i Egei w epoce brązu były bodźcem do wymiany wielu dóbr przez różnorodne powiązania. Dobra pochodzące z takich obszarów jak wybrzeża Morza Bałtyckiego wchodziły w system obrotu handlowego w centrach systemu-świata, jednak obszary te nie były faktycznym elementem systemu-świata, były zawsze marginesem. Części tego systemu-świata zdaniem Sherratta (1993) istniały w neolicie i trwały do czasów historycznych, ale nie bez zmian. Handel metalami, w tym brązem, był szczególnie ważny w systemie-świecie. Płynność handlu brązem uczyniła możliwym integrację regionalnych cykli wymiany. Andrew Sherratt (1993) sugeruje, że epoka brązu jest tak trafnie nazwana nie z powodu brązowych wyrobów, lecz ponieważ stop tego metalu napędzał ekonomiczną ekspansję, od której zależało istnienie wielu wczesnych państw.

\section{NICK KARDULIAS I EGEJSKI SYSTEM-ŚWIAT EPOKI BRĄZU}

Obszar kultury egejskiej jest ograniczony przez ląd grecki na zachodzie, Macedonię i Trację na północy, Anatolię na wschodzie i Kretę na południu, kontynentalne wybrzeża tego obszaru są mocno rozcięte i oferują liczne dobre miejsca zakotwiczenia statków. Przez tysiąclecia surowy klimat morski zmuszał ludzi tego regionu do spoglądania na morze jako największy szlak handlu i komunikacji. Ludzkie osiedlenie się w tym regionie datuje się na dolny paleolit. Nagły wzrost tego regionu, czyli polepszenie poziomu rozwoju gospodarczego, społecznego oraz politycznego nastąpił dopiero w czasach neolitycznych. Z wyjątkiem Krety i kilku Północnych Sporad żadna $\mathrm{z}$ wysp egejskich nie była zasiedlona aż do czasów neolitycznych. Epoka brązu jest jednak okresem znaczącego wzrostu liczby osad, ich wielkości i złożoności.

Warunki dla stratyfikowanej społeczności rozwinęły się w III tysiącleciu p.n.e. i rozkwitły w organizację na poziomie państwa w następnym tysiącleciu. Badacze wysuwali różne argumenty na temat pierwotności różnych czynników w pojawieniu się tych wczesnopaństwowych ustrojów, reprezentowanych przez wielkie pałace w Mykenach, Knossos, Pylos i w innych miejscach. Podkreślano rolę społecznego 
gromadzenia się w redystrybutywnej gospodarce. Na przykład Colin Renfrew w 1972 roku zaprezentował wiele hipotez na temat początków złożoności w archaicznej Grecji. Zgodnie z modelem żywnościowo-redystrybucyjnym C. Renfrewa można twierdzić, że początki uprawy winogrona i oliwek, a także ich obróbka na wino i oliwę stymulowały uprawę obszarów marginalnych we wczesnej epoce brązu i doprowadziły do wzrostu populacji, co z kolei skutkowało stratyfikacją społeczną przez nierówną dystrybucję bogactwa wytwarzanego przez system rolniczy. W specjalizacji rzemieślniczej modelu dobrobytu C. Renfrew (1972) twierdzi, że specjalizacyjna produkcja i handel wytwarzały bogactwo i stymulowały podziały społeczne oparte na hierarchii. Antonio Gilman (1981) sugeruje, że elity sponsorowały przedsięwzięcia rolnicze, ponieważ „udomowione” produkty dostarczały większość handlowych materiałów, dzięki którym elity osiągały swój wywyższony status. Te i inne poglądy przypisują handlowi szczególną wagę w ustanawianiu i utrzymywaniu złożoności społecznej. Handel jest tylko jednym aspektem powiązań miedzy centrum-peryferią, mimo tego autorzy koncentrują się na handlu, pomijając inne aspekty życia gospodarczego.

Nick Kardulias (1999) zajął się siecią wymiany w Egei, jako ogólnym systemem, i potem powiązał go z kilkoma szczególnymi materiałami, szczególnie obsydianem i metalami: miedzią i brązem. N. Kardulias (1999) sugerował, aby sprostowanie systemu opisane przez Christophera Chase-Dunna i Thomasa Halla (1991) było także wiążące dla epoki brązu w basenie Morza Śródziemnego. Szczególnie do zastosowania jest ich pojęcie różnicowania centrum-peryferie, z kilkoma modyfikacjami, do sytuacji wysp egejskich w epoce brązu. Podczas gdy oni widzą społeczeństwa na różnym poziomie społeczno-politycznej integracji, społeczeństwa wchodzące w skład takiego systemu Nick Kardulias charakteryzuje jako przypadki, w których grupy, które są zaangażowane w te interakcje, są na tym samym poziomie złożoności, to znaczy, że są one równorzędnymi jednostkami politycznymi, zwanymi w terminologii wprowadzonej przez Colina Renfew i Johna Cherry (1986) peer polity. Co więcej, ten szczególny system w Egei ma trzy wzajemnie powiązane, ale także odrębne poziomy:

1) wewnętrzny - takie sieci działały w obrębie wąsko zdefiniowanych regionów, w których transport lądem czy krótkie wyprawy wzdłuż wybrzeża wystarczały do przekazywania dóbr. Systemami lokalnymi tego typu byłyby Kreta, Cypr i Półwysep Argolidzki. Na każdym obszarze istniały grupy względnie małych państw opisywanych przez Renfrewa jako moduły wczesnopaństwowe. W obrębie każdej jednostki politycznej (polity) była pewna liczba osad, które wymieniały różnorodne dobra. N. Kardulias nie chce przez to powiedzieć, że wymiana była egalitarna. Niektóre jednostki i osady z pewnością działały jako kluczowe punkty w systemie i wypuszczały znaczące ilości dóbr. N. Kardulias twierdził raczej, że była tam równowaga w strukturze ekonomicznej w obrębie każdej jednostki politycznej i że większość modułów wczesnych państw była także równorzędna. Zaangażowana w taką wymianę byłaby pew- 
na ilość dóbr, czy to lokalnych dla każdego regionu, czy też łatwo osiągalnych przez region;

2) pośredni - ten system obejmował cały obszar Egei, a więc podróż morską między wyspami oraz lądem stałym. Badacze stworzyli różnorodne schematy, aby ukształtować tę interakcję. Cherry i Davis (cytowani przez Karduliasa, 1999) zaproponowali system wymiany zachodniego łańcucha w zachodniej części Morza Egejskiego między Attyką i Thirą (Santoryn), a inni sugerowali talassokrację minojską, w której Kreta rządziła olbrzymim komercyjnym imperium. Knapp (cytowany przez Karduliasa, 1999) zaprzecza istnieniu takiego komercyjnego monopolu. Czy jedna polity, czy wyspa była lepsza w tym handlu, czy nie, wymiana zachodziła między jednostkami o mniej więcej równej pozycji. Dobra zaangażowane w tę sieć prawdopodobnie obejmowały żywność, ceramikę i pewne nieosiągalne lokalnie prestiżowe towary;

3) dalekosiężny - w tej kategorii były połączenia ze społeczeństwami poza obszarem egejskim, obejmujące Bliski Wschód, wnętrze Anatolii oraz Egipt. Dostępne dowody wskazują, że ta sięgająca poza archipelag wymiana obejmowała różnorodne dobra, włączając w to żywność, dobra użytkowe, ozdoby. System połączył obszar mykeński i minojski razem z wielkimi imperiami północnej Afryki i Lewantu, lecz żadna ze stron nie zdominowała drugiej, chociaż w obie strony działały wpływy ekonomiczne, artystyczne itp. Jeżeli użyjemy języka teorii systemów-światów, była tam interakcja między centrum a centrum. Według Andre G. Franka (cytowany przez Karduliasa, 1999), być może to na tym poziomie można postrzegać na dużą skalę system epoki brązu przenikający cały Bliski Wschód i sąsiednie obszary takie jak Egea. A. G. Frank także przedyskutował cykliczną ekspansję i wycofanie się systemu-świata epoki brązu. On także sugeruje, że okres 1400-1200 p.n.e., który zbiega się z późną epoką brązu w Egei i będzie centrum dyskusji poniżej, był ogólną fazą ekspansji.

Andrew i Susan Sherrattowie (1993) omawiają rozwój systemu-świata Morza Śródziemnego w I tysiącleciu p.n.e. w podobny sposób. Sugerują oni, że w opozycji do epoki brązu, epoka żelaza i jej gospodarka prezentują znaczące lokalne zróżnicowanie jako rezultat tego, że ludzie odnoszą korzyści z możliwości regionalnych. Podczas gdy N. Kardulias wierzy, że gospodarka epoki brązu także miała znaczące regionalne zróżnicowanie oraz zgadza się z A. Sherratem, że system był wysoce płynny i że jednostki odgrywały aktywną rolę w kształtowaniu sieci wymiany.

\section{SYSTEM WEWNETRRZNY}

Pewna liczba archeologicznych odkryć poświadcza istnienie całkiem rozległego systemu wymiany w prehistorycznej Egei. Dystrybucja dóbr nielokalnych zaczęła się w górnym paleolicie, trwała w mezolicie, osiągnęła szczyt w neolicie, a swoją 
kulminację miała jako rozległy system epoki brązu. Dla wcześniejszych okresów obsydian jest dobrym wskaźnikiem zakresu systemu. Studia źródłoznawcze przeprowadzone przez Colina Renfrewa w 1972 roku i jego kolegów wskazują, że obsydian z wyspy Melos był szeroko rozpowszechniony w Egei, zaczynając od górnego paleolitu. Dla neolitu obsydian jest odkrywany w Argissa Magoula, Sesklo, Rakhmani, Dhimini, Tsangli i innych miejscach w Tesalii. Stanowiska macedońskiego neolitu z obsydianem obejmują Servia, Nea Nikomedia, Soufli i Sitagroi. Miejsca neolityczne południowej Grecji z obsydianem to: Tsoungiza, Nemea, Baroutospilia i Lerna I. Kontekst wyspowy obejmuje Kephala na Kea, Knossos na Krecie, Saliagos na Antiparos i Jaskinię Aspripetra na Kos.

Podczas epoki brązu wzrasta liczba stanowisk, na których występuje obsydian, jak również liczba wyrobów z tego surowca. Obszarami, na których w Grecji występuje obsydian, są m.in. Mykeny, Tiryns, Lerna, Prosymna i wiele punktów już archeologicznie zlokalizowanych przez systematyczne badania Messenii i południowej Argolidy. W dodatku wiele prac na stanowiskach z listy neolitycznej trwa nadal i nadal ujawnia artefakty z epoki brązu. Wśród kluczowych stanowisk na wyspach tych obszarów są takie punkty, jak Agia Eirini na Kea, Debla, Myrtos, Mochlos na Krecie, Phylakopi na Melos, Akrotiri na Thera, Kastri na Kythera i kilka stanowisk na Dodekanezie. Nie jest to oczywiście wyczerpująca lista, ale raczej służy ona dostarczeniu sensu geograficznej mapie znalezisk. Obok obsydianu handlowano również kamieniami milowymi wykonanymi z andezytu. Ich źródło zostało zidentyfikowane w Egei, a sama wymiana obsydianu i andezyty wskazuje na istnienie znaczącego handlu w neolicie i w epoce brązu w Egei.

Kluczowym punktem w obserwacji obsydianu jest konstatacja, że osoby, które docierały na Melos, miały bezpośredni, bez przeszkód, dostęp do tego surowca. Wydaje się, że podróżnicy wycinali stożkowe rdzenie, które transportowali następnie do swoich domostw, aby obrobić je narzędziami. Dystrybucja obsydianu sugeruje, że ludzie z Cyklad, Krety i lądu greckiego mieli możliwość i wiedzę, aby nabyć i obrobić ten materiał. Jeżeli naprawdę pojawiłyby się jakieś regulacje handlu obsydianem, wydaje się, że taka kontrola zaczęłaby się w miejscu wybrzeży, dokąd stożkowate rdzenie przybywały. Stanowiska w najbliższej fizycznej bliskości Melos mają najwięcej rdzeni; kiedy odległość od źródła wzrasta, rdzenie znikają, podczas gdy przeważają w źródłach archeologicznych ostrza jako już przetworzony wyrób z obsydianu. Nick Karudulias (1999) zauważa względną obfitość rdzeniowych ostrzy w Argolidzie i towarzyszącą im dużą ilość pozostałych wyrobów czy odpadków z tego surowca. To kontrastuje z sytuacją w Servii w Macedonii, gdzie wykonane ostrza już wydają się importowane, ponieważ podczas wykopalisk nie wydobyto żadnych rdzeni obsydianu. Podobne warunki z rdzeniami i ostrzami wydają się istnieć na Krecie w Mochlos, ale tylko ostrza występują w Debli i Myrtos. N. Kardulias sugeruje, że mimo jednej lub dwóch społeczności przejściowych (gateway community), dystrybucja obsydianu jest względnie jednorodna we wszystkich po- 
szczególnych regionach. W dodatku wzory wydają się takie same między regionami i sugerują, że moduły wczesnych państw utrzymywały pewną wewnętrzną spójność. Tablice z pismem linearnym B z archiwów pałacowych, szczególnie te z Pylos i Knossos, dostarczają wystarczających szczegółów na temat innych aspektów wewnętrznego systemu ekonomicznego. Ich odkrywca John Chadwick, cytowany przez Nicka Karduliasa (1999), przeanalizował wiele aspektów życia mykeńskiego na podstawie tych dokumentów. Tabliczki z Pylos wskazują, że państwo składało się z szeregu społeczności zwanych damos, bezpośrednio powiązanych z pałacem. Król wanax stał na czele społecznej hierarchii, w której ziemia była przypisywana przez tytuł. Główni dzierżawcy i poddzierżawcy administrowali i pracowali na ziemi rolniczej, produkowali wystarczające ilości pszenicy i jęczmienia. Znacząca ilość ziarna była następnie transportowana do magazynów pałacowych, z których racje były wydzielane niewolnikom i innym, którzy pracowali w rzemiośle pałacowym. W czasach zapotrzebowania magazyny pałacowe wyżywiły znaczącą liczbę mieszkańców regionu. Inne rolnicze produkty włączane do tego systemu redystrybucji to: oliwki, wino, figi, miód i zwierzęta. Wyobrażenie, jakie wyłania się z tekstów, to scentralizowany system, w którym dzierżawa ziemi zależy od relacji jednostki z pałacem. Jeśli spojrzeć na Pylos, Knossos czy Mykeny, system przejawia znaczący stopień jednorodności. Produkty rolnicze znajdowały swoją drogę do centralnych magazynów, a mniejsze ilości wracały później przez kanały dystrybucyjne. Ważnym pytaniem jest, czy ta pałacowa gospodarka tworzyła systemy rynkowe? Nie ma śladów rynków w tekstach napisanych pismem linearnym B, ale one zajmują się tylko przepływem dóbr do i z pałacu. Jest jednak wzmianka o prywatnej własności i jest nacisk położony na zysk, czy to ze zboża, czy z drugorzędnych zwierzęcych produktów, szczególnie wełny. W dodatku trudno sobie wyobrazić, że mieszkańcy wsi i osad nie zbieraliby się okresowo na wymianie tego, co pozostało po zapłaceniu podatku dla pałacu. Chadwick sugeruje, że rynek istniał, ale pytanie dotyczy tego, czy istniała regularna klasa kupców?

\section{SYSTEM POŚREDNI}

Wymiana materiałów z wyspy na wyspę w Egei najlepiej reprezentuje ten poziom egejskiego systemu światowego. Przez ten system produkty wyjątkowe dla poszczególnych części Egei odnajdywały swoją drogę do wszystkich kątów archipelagu. W dodatku im bardziej produkcyjne były obszary takie jak Kreta, znajdowały one wyjście dla swoich nadwyżek. Bardzo mocno dyskutowane pytanie o minojskiej talasokracji w swej istocie dotyczy tego, czy Cyklady, Dodekanez i ląd grecki były peryferiami pod dominacją centralną Krety. Chociaż Arthur Evans nie wyrażał tego w kategoriach systemów-światów, już w 1921 roku dostarczył wczesnego opisu tej perspektywy. Wierzył on, że cywilizacja mykeńska nie tylko otrzymywała twórczy 
bodziec z Krety, ale także, że ląd był pod ekonomicznym, politycznym i artystycznym wpływem minojczyków. Nick Kardulias (1999) wysuwa założenie o niezależności Myken, otwierając przez to drogę do bardziej interaktywnego modelu egejskiej ekonomii epoki brązu. Dane archeologiczne wskazują na symetryczne ekonomiczne relacje wśród wielu osad, ale jest także dowód na to, że kreteński nacisk tworzył pewien brak równowagi. W II tysiącleciu p.n.e. kultura Cyklad była wielką i bogatą tkanką osadniczą z unikalną ekspresyjną sztuką oraz dobrobytem materialnym. Większość tego bogactwa prawdopodobnie wywodziła się z tego, że różne wyspy służyły jako punkty handlowe w komercji pomiędzy Kretą, lądem greckim i obszarami bardziej położonymi na wschód. System wymiany łańcucha zachodniego łączył Kea, Melos i Therę w handlowe relacje z Attyką i Kretą. Z Laurion w południowo-wschodniej Attyce transportowany był ołów, używany do nitów, wtyczek i wodoodpornych okładzin do pojemników, oraz srebro, ważny środek wymiany w całym regionie. $\mathrm{W}$ drugą stronę wędrowała minojska ceramika, rożne wytwarzane przedmioty prestiżowe i prawdopodobnie wełniane tekstylia. Kiedy system handlu stał się niezwykle ważny dla Krety, dowody na infiltrację minojską wzrastają. Zauważalny jest minojski wpływ na ceramikę, planowanie miast i wyraz artystyczny w rożnych ważnych stanowiskach, takich jak Akrotiri na Therze i Trianda na Rodos. Z takich dowodów Nick Kardulias (1999) wywodzi twierdzenie, że mieszkańcy pochodzenia minojskiego i ich potomkowie byli obecni na Cykladach i Dodekanezie, ale natura kontaktów mogła obejmować codzienne, nieoficjalne migracje na małą skalę obejmującą kupców czy też ekspandującą elitę minojską, usiłującą wyodrębnić dla siebie dochody czy też szlachtę kreteńską, sprawującą luźną dyplomatyczną kontrolę. Pośredni egejski czy też regionalny system-świat dawał zysk wielu lokalnym społecznościom i tworzył przynajmniej luźne konfederacje, w obrębie których Kreta nie mogła narzucić hegemonii nawet mimo jej dynamicznej gospodarki, a elity wytwarzały większość popytu na dobra, które podnosiły produkcję i były bodźcem dla handlu. Podczas gdy pewne jednostki mogły wymagać kontroli systemu, nie mogły go w pełni eksploatować z powodu liczby pośredników i ich względnej izolacji na wielu wyspach.

\section{SYSTEM DALEKOSIĘŻNY}

Handel obsydianem i pewnymi innymi dobrami wydaje się ograniczony do bezpośredniego regionu wokół Morza Egejskiego. Inne przedmioty podróżowały dużo dalej i sprawiały, że świat egejski wchodził w kontakt z cywilizacjami bliskowschodnimi i strefami peryferyjnymi. Bogactwo dowodów pojawia się od późnej epoki brązu, szczególnie około 1400 roku p.n.e. Z tego okresu pochodzi wrak statku badany przez George Bassa i jego kolegów (1986, 1989). Ulu Burun, w pobliżu południowo-zachodniego krańca Anatolii, był statkiem kupieckim wracającym 
z ekspedycji w Lewancie i na Cyprze. Statek zawierał zarówno surowce, jak i wytworzone dobra. Do tej pierwszej kategorii zalicza się miedź oraz cynowe stopy w kształcie płyt, sferyczne stopy szkła, nieopracowaną kość słoniową i hipopotamów, trójsiarczek arsenu (barwnik), mirrę oraz kadzidło i dwie kłody egipskiego hebanu. Żywność obejmowała granaty, figi, winogrona, oliwki, migdały, żołędzie, szafran, pszenicę, jęczmień, kolendrę i prawdopodobnie wino oraz oliwę z oliwek, co dowiedzione jest na podstawie wielkiej liczby amfor. W skład towaru transportowanego statkiem wchodziło także szacowane na metryczne tony żywicy używanej w produkcji aromatycznych olejków i maści. Wykończone przedmioty, włączając $\mathrm{w}$ to cypryjską ceramikę, ceramikę z Syrii i Palestyny, ozdoby złote i srebrne w formach z Kanaanu, narzędzia brązowe i broń, odważniki z hematytu, artefakty kamienne, paciorki z fajansu, szkła i bursztynu, dwie kaszyckie, czyli pochodzące z Bliskiego Wschodu, pieczęcie cylindryczne. Statek płynął ze wschodu na zachód, kiedy nastąpiła katastrofa. Pulak (cytowany przez Karduliasa, 1999) sugeruje, że statek był pochodzenia mykeńskiego, z zawijaniem do portów syryjskich, takich jak Ugarit i Cypr, być może zmierzał on na Rodos lub do wybrzeża Anatolii. Z wielkim prawdopodobieństwem większa ilość miedzi była przeznaczona dla Krety i wówczas kolejna kontynuacja do Egiptu była możliwa. Połączenie Egipt - Egea jest dobrze widoczne na podstawie źródeł archeologicznych. W egipskich tekstach i w sztuce nagrobnej jednostki zidentyfikowane jako Kreteńczycy, ubrani na sposób minojski, są przedstawieni jako dostarczający dobra dla faraona i innych członków elity. W dodatku znaczna ilość ceramiki minojskiej wydaje się pojawiać w egipskim kontekście. Ze źródeł archeologicznych wynika, że statek Ulu Burun nie był unikalny i że rozległa sieć łączyła Egeę bezpośrednio z północną Afryką, Lewantem, Cyprem i wybrzeżem Anatolijskim. Poza bezpośrednimi powiązaniami pośredni handel łączył Egę z lądem anatolijskim oraz Mezopotamią.

Handel metalami jest najlepszym przykładem międzynarodowej komercji, w którą angażowali się mieszkańcy wysp egejskich. Pożyczając od Philipa Kohla pojęcie prowincji metalurgicznej, Nick Kardulias (1999) sugerował istnienie egejskiej czy też wschodnio-śródziemnomorskiej prowincji metalurgicznej, która w sposób oczywisty przedstawia system-świat, lecz taki z relacjami centrum-centrum. Andrew Sherratt (1993) twierdził, że brąz był priorytetowym dobrem, którego przepływ ułatwiał integrację regionalnych systemów wymiany. Zarówno Kardulias (1999), jak i Sherrat (1993) wskazują, że popyt elity na brąz w dużym stopniu był bodźcem do produkcji tego metalu. W egejskiej epoce brązu był brąz decydującym surowcem, ponieważ z niego była wykonana broń, narzędzia, był też ważny dla konstrukcji wielkich pałaców oraz przedmiotów prestiżowych. Weiner (cytowany przez Karduliasa, 1999) twierdzi, że polityczne i ekonomiczne bezpieczeństwo elit minojskich zależało od brązu, tak więc pozyskanie metalu było przedmiotem intensywnego planowania, poszukiwań i inwestycji. Podobny argument wysunięty jest dla tej samej epoki w Mezopotamii. Sugeruje on, że zmiana z rogu na miedź, a następnie na 
brąz w produkcji sierpów i innych narzędzi przedstawia ekonomiczną i prawdopodobnie polityczną centralizację, ponieważ metal jest rzadszy i trudno go otrzymać. W dodatku model ten twierdzi, że dobra luksusowe stały się koniecznością w handlu w Zatoce Perskiej.

Wiemy już, że handel jest tylko jednym z aspektów relacji centrum-peryferia i nie może być zrozumiany bez rozważenia obronności, dyplomacji, hegemonii kulturowej i społecznego kontekstu produkcji oraz konsumpcji w sposób, w jaki opisują Christopher Chase-Dunn i Thomas D. Hall (1991). Aby zrozumieć kontekst kulturowy i charakter takich czynności, trzeba rozważyć systemy pozyskania, produkcji i konsumpcji. Nick Kardulias (1999) rozważa więc każdy z tych aspektów w systemie gospodarczym Egei.

Dostarczanie i pozyskanie wymagało rozległych kontaktów. Egea ma tylko kilka dużych źródeł miedzi. Analizy izotopu ołowiu wskazały kilka kluczowych źródeł wyrobów z epoki brązu, które obejmowały Kithnos, Sifnos, Laurion i Cypr, z tymi dwoma ostatnimi jako najważniejszymi dla późnej epoki brązu.

Innym newralgicznym składnikiem wymaganym, aby robić dobry stop brązu była cyna, która jest znacznie rzadsza niż miedź. Istnieje debata na temat źródeł cyny używanej do wytwarzania egejskich brązów. Nick Kardulies (1999) sugerował trzy możliwe łańcuchy wysp, które obejmowały główne szlaki w Egei, szczególnie minojskie poszukiwania miedzi i cyny. Jeden biegł na północ przez Therę, Naxos, Keę aż do Laurion, był to łańcuch zachodni. Drugi biegł na wschód do Cypru i dalej do Lewantu i być może do Mersin w południowej Anatolii z przystankami w Kasos, Karpathos, Chalki, Trianda na Rodos. Trzeci szlak biegł wzdłuż zachodniego wybrzeża Anatolii do Knidos, Iasos, Miletos, Teichiussa, a potem do Troi przez Samos. Przystanki na tym szlaku mogły obejmować Kalymnos, Telos, Nisyros, Astypalaia i Kos. Oczywiście kupcy egejscy tylko wykupowali stopy w wielu tych portach. Wrak Ulu Burun daje nam wskazówkę o tym, jakie ilości mogły wchodzić w rachubę. Statek przewoził około 300 stożkowatych stopów miedzianych, każda ważyła po $25 \mathrm{~kg}$ i tuziny stopów cyny. Ilości te przewyższają zanotowane ilości w wielu starożytnych bliskowschodnich tekstach. Jeżeli założymy, że ten towar na statku był ogromny, ale nie unikalny, mamy jakieś wyobrażenie o skali handlu metalami.

Drugi równie ważny problem to ocena sieci handlowej i administrowania systemu. Oczywiste jest, że aż do późnej epoki brązu ląd grecki miał dobrze rozwiniętą biurokrację pałacową, która rejestrowała handel metalami. Nie jest pewne do końca, czy pałac regulował i finansował handel dalekosiężny, czy też niezależni kupcy sami podejmowali przedsięwzięcia. Niektórzy sugerują, że handel metalami był wolny. Nick Kardulias zgadza się jednak, że rola miedzi, brązu i innych metali dla elit była o takiej wartości, że ekspedycje były planowane i finansowane przez pałac. Ważność miedzi i brązu została scharakteryzowana wyżej. Z obrazu dystrybucji artefaktów brązowych wynika, że były one dostępne tylko dla osób uprzywilejowanych, czyli elity. Równie ważna jest ewolucja pisanych tekstów, przez które pałace admi- 
nistrowały, zarządzały handlem metalami. Kardulias twierdzi (1999), że system administracyjny oparty na pieczęciach i piśmie został zapożyczony z Bliskiego Wschodu jako rezultat kontaktów komercyjnych. Podczas gdy nie ma wątpliwości dotyczących zapoznania się świata egejskiego z bliskowschodnimi ludami i produktami, proces dyfuzji artefaktów pochodzących z obu regionów jest bardziej złożony. Kardulias (1999) wskazuje, że kiedy Cypr staje się wielkim dostawcą miedzi dla Krety, administracja cypryjska wybiera raczej pismo linearne A, obowiązujące na Krecie, niż pismo klinowe rozpowszechnione we wschodniej części Morza Śródziemnego jako pismo w administracji. Jak przypuszcza Weiner (cytowany przez Karduliasa, 1999), jakaś część handlu w danym okresie mogła zachodzić bez użycia pisma. Mimo to powstała w tym czasie złożona administracja, a także rozwój budowy statków, portów, całej infrastruktury dokonywanej wraz z upływem czasu, gdy handel ulegał intensyfikacji, wymagały dokumentów. Tak więc egejski system-świat obejmował pojawienie się hierarchii społecznej, ale żaden z większych partnerów handlowych nie miał zdolności do zdominowania tego drugiego, to znaczy nie ma rozwoju klasycznych relacji zależności miedzy centrum i peryferią.

Produkcja obejmowała kilka różnych poziomów. Wytapianie często odbywało się obok miejsca wydobycia. Alternatywnie pewne miejsca pośrednie między miejscami wydobycia w głębi lądu i wybrzeżem dostarczały tej usługi. Na przykład stanowisko Pamboulari tis Koukouninas w pobliżu Athienou w centralnym Cyprze jest na pewną odległość od zarówno przynoszących miedź gór i morza. Keswani (cytowany przez Karduliasa, 1999) twierdzi, że było tam osiem produkujących miedź jednostek politycznych w późnej epoce brązu i te centra dostarczały surowca dla wysp egejskich. Stopy były później transportowane na obszary wybrzeża. W niektórych tekstach są wspominane karawany złożone z osłów, a dalej przekazywanie towarów na statki, które rozwoziły je do rożnych miejsc na Morzu Egejskim. Przekształcenie stopów w skończony produkt odbywało się pod strażą administratorów pałacu. Najlepszy dowód na istnienie takiego systemu, który opisałam wyżej, pochodzi z tabliczek z Pylos, które były traktowane jako zapiski, jako chwilowy zapis podstawowych rachunków, dlatego wykonano je z niewypalonej gliny. Pożar, który zniszczył ten pałac około 1200 roku p.n.e., przyczynił się do wypalenia owych tabliczek i tylko dzięki temu możliwe stało się ich zachowanie i odczytanie współcześnie. Tak więc tabliczki te dostarczają inwentarza z jednego sezonu czy też, w najlepszym razie, jednego roku w systemie pałacowym. Skrybowie notowali ilość brązu z magazynów pałacowych asygnowaną kowalom w pałacu i w otaczających pałac społecznościach. System wagowy i częściowy zezwalał na dokładne notowanie ilości tak asygnowanych. Kowale i metalurdzy mogli pojawić się jako specjaliści w epoce środkowego brązu. Został odkryty sklepwarsztat kowalski w Malthi na Messeni i być może drugi w Lerna w Argolidzie, w okresie przedpałacowym, na lądzie greckim. Każda tabliczka w serii Jn z Pylos dostarcza nazwy miejsca, listy kowali i ilość brązu asygnowaną każdemu oraz liczbę 
całkowitą. Jest też powszechna inna lista kowali, którzy nie otrzymali żadnego metalu. Wydaje się, że w przybliżeniu $1 / 3$ wszystkich kowali nie opracowywała metalu w czasie, kiedy tabliczki były pisane. Ci, którzy pozostali bez metali, mogli być zaangażowani w produkcję żywności i sugerowałoby to obecność specjalistów tylko na pół etatu, którzy mogli być wzywani wtedy, gdy okoliczności wymagały więcej profesjonalnej siły roboczej. John Chadwick (cytowany przez Nicka Karduliasa, 1999) szacuje, że w królestwie Pylos było blisko 400 kowali. Kontrola pałacu przemysłu metalowego jest sugerowana nie tylko przez wypłaty zanotowane na tabliczkach, lecz także przez koncentrację kowali w pewnych regionach, z około 26 osobami w jednym miejscu. Ilość brązu asygnowana dla każdego kowala jest względnie mała, sięga od $1,5 \mathrm{~kg}$ do $12 \mathrm{~kg}$, a przeciętnie to 3-4 kg. Całkowita ilość jest znacząca: jedna $\mathrm{z}$ tabliczek notuje $1,046 \mathrm{~kg}$, a inna $1,562 \mathrm{~kg}$. Rzemieślnicy wykonywali cały asortyment wyrobów brązowych: naczynia, kubki, podgrzewacze, noże, siekierki, topory, pincety, brzytwy, piły, dłuta, szydła, szalki do wagi, lampy i szeroki asortyment wyposażenia wojskowego, włączając w to sztylety, miecze, ostrza włóczni, ostrza strzał, uzbrojenie, hełmy oraz okucia rydwanów i kół wozów. Szacunki sugerują, że z tony brązu kowal mógł wytopić 534000 grotów strzał czy 1000 hełmów.

Równie ważne jak produktywność, są relacje produkcji. Jak już wyżej wspomniałam, kowale byli pod kontrolą pałacu. Pracowali, w dużej części, pod nadzorem centralnej administracji, która gromadziła dostawy surowca. Mimo ilości wymienionych na tabliczkach, brąz był ogólnie niedostępny i urzędnicy pałacowi regulowali jego przepływ. John Chadwick, cytowany przez Nicka Karduliasa (1999), odkrył, że administracja w pałacu Pylos prowadziła bardzo restrykcyjny system racjonowania dóbr. Brąz był we względnie małych ilościach i jego użycie było priorytetowe dla wojska. Tabliczka Jn 829 w szczegółach pisze o wkładzie brązu od lokalnych zarządców wymaganego przez pałac, po to, aby zrobić groty do oszczepów i włóczni. Zakłada się, że brąz był najpierw gromadzony i następnie dystrybuowany do kowali, którzy topili artefakty i produkowali broń, która była z kolei zwracana do pałacu. Są też inne dowody świadczące o zaistnieniu kryzysu. Tabliczki An 657, An 654, An 519, An 656, An 661 wspominają o strażnikach pilnujących wybrzeża i strzegących nadbrzeżnych regionów, którzy byli bezpośrednio nadzorowani przez królewskich urzędników. Z kolei zniszczenie pałacu jest niemym dowodem na niezdolność administracji pałacowej do opanowania sytuacji. Metalurdzy brązu mogą zostać zaklasyfikowani jako specjaliści, których rola jako rzemieślników była dotowana, kierowana i w dużej części rozwijana z powodu potrzeb elity pałacowej. Pałac wspierał także innych rzemieślników, takich jak garncarze, malarze fresków, architekci, rzeźbiarze, szlifierze drogich kamieni, duża ilość ich produktów kończyła w magazynach pałacowych. Aby być pewnym, trzeba też założyć istnienie innych, niewspomnianych dotąd, rzemieślników, których praca dostarczała różnych dóbr i usług. Ekonomiczna specjalizacja wydaje się raczej scentralizowana. 
Wyroby metalowe były w dużym stopniu konsumowane przez elitę. Duże ilości mieczy brązowych, sztyletów oraz uzbrojenia odkrywana jest w grobach mykeńskich i minojskich. Te przedmioty prawdopodobnie reprezentują militarną naturę hierarchii, która trzymała się dalej na greckim lądzie i w Knossos w późnej epoce brązu. Anthonio Gilman (1981) twierdzi, że takie przedmioty w europejskiej epoce brązu sugerują dominację klasy wojowników. Nic, co pochodzi z egejskiego kontekstu, nie zaprzecza temu twierdzeniu. Grób szybowy z kręgu grobów A w Mykenach datowany na wczesnomykeński okres: późną epokę brązu, czyli około 1550-1450 p.n.e., dostarcza dobrych danych do twierdzenia o koncentrowaniu wyrobów brązowych przez elity. Częściowy inwentarz z grobu szybowego IV z kręgu grobów A obejmuje 3 złote maski, 2 złote korony, 8 złotych diademów, 27 mieczy, 5 sztyletów, 16 noży, 5 brzytw, 22 brązowe wazy, 38 grotów strzał, 683 złotych dysków oraz innych ozdób. Jest też całkiem sporo innych wyrobów, ale nawet ta niekompletna lista darów grobowych demonstruje wywyższony status tych, którzy byli tam pochowani. W dodatku do brązu inne materiały o obcym pochodzeniu były odkrywane w grobach: jaja strusia pochodzące z Nubii, lapis lazuli od Afganistanu po Mezopotamię, alabaster i fajans z Krety, kość słoniowa z Syrii, srebro z Anatolii, bursztyn $\mathrm{z}$ regionu Bałtyku. Wykopaliska na stanowiskach egejskich $\mathrm{z}$ epoki brązu przez ostatnie 125 lat ujawniały zdecydowanie rosnącą tendencję dystrybucji takich materiałów. Przedmioty luksusowe występowały w dużych ilościach w grobach i w poziomach destrukcji pałaców, w większości centrów i w mniejszej ilości w dużych rezydencjach, na drugorzędnych stanowiskach. W dodatku do konsumpcji domowej wyroby metalowe prawdopodobnie były kluczowymi wyrobami w wymianie między egejskimi jednostkami politycznymi oraz z bardziej odległymi członkami systemu-świata, takimi jak Egipt, Anatolia, Syria. John Chadwick (cytowany przez Karduliasa, 1999) twierdzi, że sugerowana liczba 400 kowali w Pylos produkowała znaczne nadwyżki, ponad potrzeby elit i nieelit, przedmiotów brązowych, z których wiele było transportowanych morzem. Obcy handel, szczególnie ten metalami, był kluczowy dla egejskiej epoki brązu i jego zerwanie mogłoby mieć katastrofalne konsekwencje dla systemu administracyjnego pałacu. Takie zerwanie wydarzyło się w XII i XIII wieku p.n.e., a cały wschodni basen Morza Śródziemnego przeżył wtedy upadek. Gałąź egejska tego systemu już nie podniosła się po nim. Wielu badaczy sugeruje, że inwazja tzw. Ludów Morza, zanotowana w egipskich dokumentach jako seria wydarzeń w późnej epoce brązu, która odzwierciedla przemieszczenia wielkiej ilości ludzi we wschodniej części Morza Śródziemnego, naruszyła system ekonomiczny i polityczny w regionie. Upadek systemu handlu doprowadził do schyłku elity egejskiej. Być może dużo ważniejszy niż system wymiany sam w sobie był schyłek produkcji z jej stymulującym wpływem na społeczeństwo.

Podsumowując, egejski system handlowy w późnej epoce brązu był rozległy i administrowany przez pałace. Sprawiał, że w kontakcie było wiele kultur $\mathrm{z}$ bardzo 
dobrze rozwiniętymi gospodarkami i apetytem na prestiżowe i utylitarne dobra. Z powodu odległości oraz braku kontroli bezpośrednich źródeł surowców nie powstał system zależności centrum-peryferie między Egeą i innymi wielkimi społeczeństwami, głównie Egiptem, Mezopotamią, państwami Lewantu. Nie minimalizuje to znaczenia idei systemu-świata jako perspektywy dostarczającej teoretycznego podejścia do zrozumienia kontekstu interakcji. Pierwotne sformułowania Wallersteina są wystarczająco elastyczne, aby dostosować je do całkiem innych warunków ekonomicznych w starożytności. Co jest oczywiste, to fakt, że była w tamtejszym działaniu sfera interakcji na kilku różnych poziomach. Lokalny system obejmował wymianę materiałów w obrębie modułów wczesnych państw. System egejski obejmował sferę interakcji w obrębie lądu greckiego i wysp, które brały w nim udział. Z wyjątkiem możliwym dla kolonistów minojskich, na niektórych wyspach egejskich i mieszkańcami mykeńskimi w późnej epoce brązu w Knossos, jednostki polityczne centralne Egei, czyli Mykeny, Knossos, Pylos nie utrzymywały stałych siedzib na obszarach skąd pozyskiwały surowce. Wydobycie surowców było kontrolowane lokalnie. Kontakt z egejskimi modułami wczesnych państw stymulował produkcję, ale nie prowadził do politycznej dominacji. System-świat wschodniego Morza Śródziemnego był wymianą międzynarodową, która obejmowała zarówno towary masowe, jak i luksusowe do i z Egei, Egiptu, Syrii i Palestyny, Cypru, Anatolii. Bezpośrednie kontakty egejskie były ograniczone do obszarów przybrzeżnych w tych innych lądach. Sieć jednak rozciągała się daleko w głąb stref nabrzeżnych. Cyna pochodziła z głębi Anatolii, jaja strusia i złoto nawet z Nubii, aromatyczne maści z półwyspu arabskiego, pieczęcie cylindryczne z Mezopotamii. Niektóre dane sugerują, że wydobycie surowców na niektórych z tych obszarów było zrealizowane w sposób bezpośredniej eksploatacji centrum nad terytoriami peryferyjnymi. Na przykład tabliczki klinowe wskazują, że kupcy asyryjscy ustanowili punkt w Kanesz (Kultepe) w centralnej Anatolii około 1950 roku p.n.e. i z tego miejsca eksportowali tony miedzi do Mezopotamii. Tekst także wyjaśnia, że Kanesz było centralnym punktem w serii 9 asyryjskich posterunków w tym regionie. Co więcej, nazwa Kaptara odnosi się do Krety, jak wierzy w to wielu badaczy, wówczas wspomnianej na tabliczkach z Mari, które piszą o człowieku z tego regionu, jako odbiorcy cyny ze wschodu. To tworzy powiązanie między mezopotamskim a egejskim systemem-światem. Podczas gdy relacje wśród różnych uczestników w splatających się systemach wymiany różniły się, widać wielką zależność obszarów miejskich centralnych od produktów czy materiałów dostępnych w strefach marginalnych. Niezdolność w wielu przypadkach centralnych państw do zwołania wystarczającej siły ludzkiej, aby podbić obszary peryferyjne, wykluczała rozwój roli zależnej od tych ostatnich. Z modyfikacjami wspominanymi wyżej, pojęcie „system-świat” będzie dobrze służył do opisywania wewnętrznych i zewnętrznych relacji w późnej prehistorycznej Egei w epoce brązu. 


\section{BIBLIOGRAFIA}

Bass G.

1986 Bronze Age Shipwreck at Ulu Burun (Ka). 1984 Campaign. American Journal of Archaeology, 90, s. 269-296.

1989 The Bronze Age Shipwreck at Ulu Burun. 1986 Campaign. American Journal of Archaeology, 93, s. 1-29.

Braudel F.

1977 Afterthoughts on Material Civilisation and Capitalism. Baltimore: John Hopkins University Press.

Chase-Dunn Ch., Hall T. D.

1991 Conceptualizing Core/ Periphery Hierarchies for Comparative Studies. W: Ch. Chase-Dunn, T. D. Hall (red.), Core/ Periphery Relations in Precapitalist Worlds (s. 5-44). Boulder: Westview Press.

Frank A. G.

1993 Bronze Age World Systems Cycles. Current Anthropology, 34, s. 383-429.

Gilman A.

1981 The Development of Social Stratification in Bronze Age Europe. Current Anthropology, 22, s. $1-23$

Kardulias P. N.

1999 Multiple Levels In the Aegean Bronze Age World-System. W: P. N. Kardulias (red.), World Systems Theory in Practice (s. 179-201). New York: Rowman and Littlefield Publishers.

Kardulias P. N.

2007 Negotiation and incorporation on the margin of world-systems: examples from Cyprus and North America. Journal of World - Systems Research XIII, 1, s. 55-82.

Kardulias P. N., Hall D. T.

2008 Archaeology and world- systems analysis. World Archaeology, 40(4), s. 572-583.

Kardulias P. N., Hall T. D., Chase-Dunn Ch.

2011 World-Systems Analysis and Archaeology: Continuing the Dialogue. Journal of Archaeological Research, 19, s. 233-279.

Polanyi K., Arensburg C., Pearson H. W. (red.)

1957 Trade and Market in the Early Empires. New York: Free Press.

Renfrew C.

1972 The Emergence of Civilisation. London: Methuen.

Renfrew C., Cherry J. F. (red.)

1986 Peer Polity Interaction and Sociopolitical Change. New York: Cambridge University Press.

Schortman E. M., Urban P. A.

1987 Modeling Interregional Interaction in Prehistory. W: M. B. Schiffer (red.), Advances in Archaeological Method and Theory (T. 11, s. 37-95). New York: Academic Press.

1992 Current Trends in Interaction Research. W: Schortman E. M., Urban P. A. (red.), Resources, Power and Interregional Interaction (s. 235-255). New York: Plenum Press.

Sherratt A.

1993 What would a Bronze Age System look like? Relations between Temperate Europe and the Meditterranean in Later Prehistory. Journal of European Archaeology, 1(2), s. 1-57. 
Sherrat A., Sherratt S.

1993 The Growth of the Mediterranean Economy in the Early First Millenium BC. World Archaeology, 24, s. 361-378.

Weber M.

1976 The Agrarian Sociology of Ancient Civilisations. New York: Humanity Press Atlantic Highlands.

\title{
IMMANUEL WALLERSTEIN'S CENTRE-PERIPHERY THEORY AND ITS RECEPTION IN ARCHEOLOGY; THE CASE STUDY OF AEGEAN BRONZE AGE WORLD-SYSTEM
}

\author{
S u m m a r y
}

The proposed article presents the application of the world-systems theory to the study of Bronze Age populations. The article focuses on the work of Nick P. Kardulias, one of the most eminent proponents of Immanuel Wallerstein's theory and its application in archaeology.

As an example I present his statements concerning the Aegean Bronze Age World-System. I did not discuss this example in my previous article, because I think that it creates the closed study. He supposes that Aegean societies in the third and second millennia B.C. developed complex economies based on the accumulation of substantial agricultural surpluses, craft specialization and intricate distribution systems. He thinks that trade items included both utilitarian and luxury goods.

According to Nick Kardulias, the study of Immanuel Wallerstein are not sufficient to deal with ancient economy. As we can remember from my previous article, I. Wallerstein did not apply his model to the precapitalist societies. Nick Kardulias sees and is aware of the limitations of I. Wallerstein's works. But he tries to cross the obstacles including in his synthesis also the works of Thomas D. Hall and Christopher Chase-Dunn and Colin Renfrew.

The work of Nick Kardulias is as the works of I. Wallerstein rich synthesis of existing points of view and theories, models concerning not only the past but also present capitalist societies. 